\title{
PENGARUH PENGGUNAAN INTERNET SEBAGAI MEDIA BELAJAR DAN MOTIVASI BELAJAR TERHADAP PRESTASI BELAJAR EKONOMI SISWA KELAS X SMK SWSATA T.AMIR HAMZAH INDRAPURA TAHUN PELAJARAN 2015/2016
}

\author{
Johnson ${ }^{1)}$, Misroh Handayani ${ }^{2)}$ \\ 1) Fakultas Ekonomi, Universitas Negeri Medan \\ 2) Fakultas Ekonomi, Universitas Negeri Medan
}

\begin{abstract}
Permasalahan dalam penelitian ini adalah rendahnya prestasi belajar siswa pada mata pelajaran ekonomi. Penelitian ini bertujuan untuk mengetahui mengetahui pengaruh penggunaan internet sebagai media belajar dan motivasi belajar terhadap prestasi belajar siswa kelas X SMK Swasta Tengku Amir Hamzah Indrapura Tahun Ajaran 2015/2016. Penelitian ini dilakukan selama satu hari di SMK Swasta Tengku Amir Hamzah Indrapura, yang beralamat di Jln. Syarifuddin No.39 Tanjung Kubah, Kecamatan Air Putih Kabupaten Batu Bara. Penelitian ini dilaksanakan pada tanggal 04 Mei 2016 dengan populasi sebanyak 67 siswa yaitu seluruh siswa kelas X AK SMK Swasta Tengku Amir Hamzah Indrapura dan teknik pengambilan sampel dalam penelitian ini menggunakan teknik sampling jenuh yang merupakan teknik penentuan sampel bila semua anggota populasi digunakan menjadi sampel yang terdiri dari 67 siswa. Data yang digunakan dalam penelitian ini diperoleh dari angket dan nilai semester genap mata pelajaran ekonomi yang diperoleh dari Daftar Kumpulan Nilai (DKN). Hasil penelitian ini menunjukkan terdapat pengaruh yang positif dan signifikan antara Penggunaan Internet dan Motivasi Belajar terhadap prestasi belajar siswa pada mata pelajaran ekonomi kelas X SMK Swasta T. Amir Hamzah Indrapura Tahun Ajaran 2015/2016..
\end{abstract}

Keywords: Penggunaan Internet, Motivasi Belajar, Prestasi Belajar 


\section{PENDAHULUAN}

Ilmu pengetahuan dan teknologi dewasa ini berkembang pesat yang mengakibatkan perubahan diberbagai aspek kehidupan terutama pada aspek pendidikan. Pendidikan merupakan sumber kemajuan bangsa yang sangat menentukan daya saing bangsa, dengan demikian sektor pendidikan harus meningkatkan mutuhnya.

Internet adalah salah satu bukti nyata pesatnya perkembangan teknologi di bidang informasi dan telekomunikasi. Internet membawa pengaruh yang sangat besar dalam pola kehidupan masyarakat dunia, khususnya Negara-negara maju. Penggunaan media pembelajaran sebagai suplemen pengajaran dikelas, akan efektif dan lebih mudah diterima.

Peningkatan prestasi belajar siswa dapat ditentukan oleh motivasi belajar yang dimiliki siswa. Siswa yang memiliki motivasi belajar makaaktivitas belajar akan baik sehingga prestasi belajar yang dicapai juga akan baik, namun sebaliknya siswa yang tidak memiliki motivasi belajar maka aktivitas belajarnya akan rendah sehingga prestasi belajar yang dicapai juga akan rendah. Ini menunjukkan motivasi merupakan penggerak atau pendorong untuk melalukan tindakan tertentu.

Motivasi ada dua macam yaitu motivasi instrinsik dan motivasi ekstrinsik, motivasi instrinsik adalah motivasi yang muncul dari dalam diri. Sedangkan motivasi ekstrinsik adalah motivasi yang muncul dari luar diri. Berdasarkan hasil observasi awal yang dilaksanakan SMK Swasta T.Amir Hamzah Indrapura, melalui wawancara dengan guru Ekonomi kelas $\mathrm{X}$ diketahui bahwa disekolah tersebut tersedia fasilitas internet namun guru kurang memanfaatkan internet dankurangnya pengetahuan guru menggunakan internet sebagai media belajar.

Rendahnya prestasi belajardapat dilihat dari kumpulan nilai siswa yang diproleh dari SMK Swasta T.Amir Hamzah Indrapura dimana nilai Kriteria Ketuntasan Minimal ( KKM ) untuk pelajaran ekonomi yaitu 75, adalah sebagai berikut :

\section{METODE PENELITIAN}

Penelitian ini dilaksanakan SMK Swasta T.Amir Hamzah Indrapura Jln. Syarifuddin No. 39 Tanjung Kubah Indrapura. Penelitian ini dilaksanakan pada semester Genap, Tahun Ajaran 2015/2016. Populasi dalam penelitian ini adalah seluruh siswa kelas X SMK Swasta T.Amir Hamzah Indrapura yang berjumlah 67 Siswa. Adapun variabel dalam penelitian ini adalah sebagai berikut.

1. Internet sebagai media belajar

Internet sebagai media belajar adalah suatu jaringan informasi yang digunakan untuk mengakses informasi selain dari buku untuk meningkatkan prestasi belajar siswa.

\section{Motivasi Belajar}

Motivasi belajar adalah dorongan intrinsik dan ekstrinsik pada siswa yang sedang belajar untuk mengadakan perubahan tingkah laku munculnya motivasi baik instrinsik maupun ekstrinsik untuk melakukan kegiatan yang dapat meningkatkan prestasi belajar siswa.

\section{Prestasi Ekonomi}

Prestasi merupakan hasil yang dicapai oleh individu setelah mengalami proses belajar dalam jangka waktu tertentu. Dalam hal ini prestasi belajar diperoleh dari DKN (Daftar Kumpulan Nilai ).

\section{HASIL DAN PEMBAHASAN}

Persamaan regresi linear berganda tersebut dapat diuraikan sebagai berikut Konstanta (a) = 16,907 artinya jika variabel independent yaitu penggunaan internet sebagai media belajar dan motivasi belajar tidak meningkat, maka tetap akan ada 16,907 prestasi belajar siswa pada mata pelajaran ekonomi kelas $X$ SMK Swasta T.Amir Hamzah Indrapura Tahun Ajaran 2015/2016

Pengaruh penggunaan Internet sebagai media belajar terhadap prestasi belajar dihitung berdasarkan berdasarkan regresi yang diperoleh yaitu 0,449 artinya,jika penggunaan internet meningkat maka prestasi belajar siswa pada mata pelajaran ekonomi kelas X SMK Swasta T.Amir Hamzah Indrapura Tahun Ajaran 2015/2016 akan bertambah sebesar 0,449.

Hipotesis dalam penelitian, jika nilai $\mathrm{t}$ hitung 6,853 > 1,997 dan signifikan 0,000 <0,05 maka hipotesis diterima. Artinya ada pengaruh positif dan signifikan antara variabel X1 terhadap Y.Jika nilai t hitung 4,745 > 1,997 dan signifikan $0,000<0,05$ maka hipotesis diterima. Artinya ada pengaruh positif dan signifkan antara variabel $\mathrm{X} 2$ terhadap Y. Jadi jika nilai $\mathrm{F}$ hitung > F tabel $(35,027>3,14)$ dan signifikan $0,000<0,05$ maka hipotesis diterima artinya ada pengaruh positif dan signifikan antara $\mathrm{X} 1$ dan X2 terhadap Y secara bersama-sama. 


\section{KESIMPULAN}

Berdasarkan hasil penggujian dan pembahasan terhadap data penelitian yang telah dikumpulkan mengenai pengaruh penggunaan internet sebagai media belajar terhadap prestasi belajar siswa pada mata pelajaran ekonomi kelas X AK SMK Swasta T.Amir Hamzah Indrapura Tahun Ajaran 2015/2016, diperoleh beberapa kesimpulan yaitu sebagai berikut terdapat pengaruh penggunaan Internet sebagai media belajar dan motivasi belajar secara simultan memiliki pengaruh yang positif dan signifikan terhadap prestasibelajar siswa mata pelajaran ekonomi kelas X SMK Swasta T.Amir Hamzah Indrapura Tahun Ajaran 2015/2016. Pengaruh penggunaan internet sebagai media belajar dan motivasi belajar secara parsial memiliki pengaruh yang positif dan signifikan terhadap prestasi belajar siswa mata pelajaran ekonomi kelas X AK.

\section{REFERENSI}

Ardy, Prasetyo. 2008. Pemanfaatan Internet sebagai Media Belajar http://wordpress.com ( diakses 10 februari 2016 )

Arikunto, suharsimi. 2010 . Prosedur penelitian suatu pendekatan praktik. Jakarta: Rineka cipta

Arsyad, Azhar. 2011. Media Pembelajaran. Jakarta: Raja Granfindo Persada

Astuti, wiwin. 2012. Pengaruh Motivasi Belajar dan Metode Pembelajaran Terhadap Hasil Belajar IPS Terpadu Kelas VIII SMP PGRI 16 Brangsong Kabupaten Kendal. Economi Analysis Journal. No 1 Hal 1-6 ISSN 2252-6544. Http://journal. Unnes.ac.id/sju/index.php/eeaj ( Diakses 17 februari 2016 ).

Bisri, dkk. 2009, Efektifitas Penggunaan Metode Pembelajaran Elearning Berbasis Browser Based Training Terhadap Prastasi Belajar Siswa pada Kompetensi Pemeliharaan /Servi s Trasmini Manual Dan Komponen. Jurnal PTM Volume 9, No 3Juni 2009, ISSN: 1412-1247

Desrianti, Dewi Immaniar, DKK. 2013. Ilearning Metode Belajar Efektif Untuk Sekolah Tinggi, Jurnal Pendidikan. Vol.7 No. 3 Mei 2014. ISSN 1978-8282.

Dimyanti dan mudjiono. 2010. Belajar dan Pembelajaran. Jakarta: Reneka Cipta

Djamarah dan Zain. 2010. Strategi Belajar Mengajar, Jakarta : Rineka Cipta
Djamrah, Bahri. 2011. Psikologi Belajar. Jakarta: Reneka Cipta

Gulham, Hamdu. 2011. Pengaruh motivasi Belajar Siswa Terhadap prestasi Belajar IPA di sekolah Dasar. Jurnal penelitian pendidikan. No. 1 hal : 90 -96 ISSN 1412-565X.http://.upi.edu/file/8-Ghulham Hamdu.pdf (Diakses 19 februari 2016 )

Oemar. Hamalik, 2010. Proses Belajar Mengajar. Jakarta:Bumi Aksara 2010. Kurikulum dan Pembalajaran. Jakarta: Bumi Aksara

Harapan, sawitri. 2014. Pengaruh Fasilitas Belajar dan Motivasi Belajar terhadap Prestasi Belajar IPS Terpadu Siswa Kelas VIII MTs AL-ITTIDAHIYAH Medan Tahun Pelajran 2013/2014 . Medan UNIMED

Istarani dan Pulungan. 2015. Ensiklopedia Pendidikan. Medan: Media Prasada

Santoso, Ario Budi. 2013. Pengaruh Fasilitas Belajar dan Motivasi Belajar Terhadap Hasil belajar Siswa pada Mata Pelajaran Ekonomi siswa kelas X di SMA Swasta Pabaku Barat TA2012/2013. Medan UNIMED.

Slamento. 2010. Belajar dan Faktor-faktor yang Mempengaruhinya. Jakarta: Rineka Cipta

Sudirman. 2011, Internet dan Motivasi Belajar Mengajar. Jakarta : Rja Grafindo Persada.

Sudjana. 2009. Metode Statiska. Bandung : Tarsito

Sugiono. 2010. Metode Penelitian Pendidikan. Bandung: Alvabeta

Sulistyowati dan Widiyanto. 2012. Pengaruh Motivasi Belajar dan Kompetensi Profesional Guru Terhadap Prestasi Belajar Mata Pelajaran IPS Ekonomi Siswa Kelas VII SMP Negeri Magelang TP 2011/2012. Economi Education Analysis journal, ISSN :2252-6544. Vol 1 No 2 Tahun 2012. Hal 1-6. http://journal. Unnes.ac.id/index.php/eeaj (Diakses 21 Februari 2016)

Sunarti, Neni. 2014. Penggunaan Internet sebagai Media Belajar Dan Motivasi Belajar Terhadap Prestasi Belajar IPS SiswaKelas VIII SMP Negeri 9 Medan TA 2013/2014. Medan UNIMED 